\title{
Språknytt for leger
}

\section{Av og til bidrar Tidsskriftet med nyord til det norske språket. Den siste tilveksten er papegøyokrati.}

Fire ganger i året kommer bladet Språknytt i postkassen. Har det interesse for flere enn språknerdene? Jeg har sett igjennom nr. $1 / 2011$ og fant mye av interesse også for leger.

\section{Nyord}

I spalten «Nyord» presenteres nykomlinger i språket. «Når et ord er ført opp i denne spalten, betyr det bare at vi har registrert at det er i bruk. Det betyr ikke at Språkrådet går god for ordet», står det. Blant nykommerne denne gang finnes «papegøyokrati». Det er hentet fra et leserbrev i Tidsskriftet av thoraxkirurg Steinar Solberg, som i nr. 21/2010 skrev: "Oslo universitetssykehus er en gullgruve for nyspråk, floskler og honnørord. En nyskapning i norske sykehus er programkontoret, hvor svært mye bestemmes i praksis. Når en sak er «på plan», betyr det på vanlig norsk at den er i rute. Vi bombarderes med «gode dialoger» og «sterke forankringer» mens følelsen av avmakt øker. «Redesign» er nå blitt et standarduttrykk. Nye, uklare og mye brukte begreper skaper avstand. En sykepleier sa: «Vi lever i et papegøyokrati.»»» (1).

I samme spalte finner vi også et annet nyord med medisinsk relevans: «ventesorg». Det er en sorgreaksjon som oppstår når man venter på et dødsfall. Det er en situasjon som mange befinner seg i når noen som står en nær, går inn i livets sluttfase pga. alvorlig sykdom eller alderdom.

Spalten «Nyord» ble lansert i Språknytt i 1977. En gjennomgang av disse nyordene viser mange medisinske ord, bl.a. klone (1978), aids (1983) og immunsvikt (1983). Men konklusjonen er at de fleste nyordene forsvinner raskt og ikke etablerer seg i ordbøkene.

\section{Elsker vi ikke språket vårt?}

Poeten Bertrand Besigye (f. 1972) sier i et portrettintervju at nordmenn skiller seg ut fra mennesker i resten av Europa. Franskmenn, italienere, tyskere - alle elsker språket sitt, mens folk i Norge ikke er så glad i å snakke norsk. De ønsker å snakke et annet språk, heller enn å nyte sitt eget. Det er som om språket ikke har satt seg dypt nok i nordmenns DNA, hevder Besigye. Han bruker også andre medisinske metaforer. I Norge er det språklige immunforsvaret nesten nede. Når det kommer press utenfra, har ikke nordmenn nok kjærlighet til språket sitt til å yte motstand, mener Besigye. Han fikk Tarjei Vesaas' debutantpris for debutsamlingen $O g d u$ dør så langsomt at du tror $d u$ lever (1993), som er tidenes mestselgende norske debutdiktsamling.

\section{Vanskelige kjønn}

På norsk har vi som kjent tre grammatiske kjønn (genus): hunkjønn, hankjønn og intetkjønn. Den grammatiske konstruksjonen genus er noe norsk deler med de aller fleste indoeuropeiske språk: tysk, fransk, russisk, urdu osv. Men engelsk, som er vår fremste leverandør av nye importord, har ikke den grammatiske kategorien genus. Det innebærer at substantiv som vi låner fra engelsk, må få tildelt et grammatisk kjønn når vi tar det i bruk i norsk.

Hankjønnsordene er den største gruppen av substantiv på norsk, så det er ikke unaturlig at ord vi låner inn, oftest blir gjort til hankjønnsord. Slike eksempler er weekend, jobb, bløff og film. Det er sjelden de engelske ordene blir hunkjønnsord. Unntaket er innlånte verbalsubstantiv, slik som doping og mobbing. Eksempler på intetkjønnsord er enkelte enstavingsord som rush, show, sjokk og stress.

Likevel lever importordene sitt eget liv blant språkbrukerne. To ord som Språkrådet ofte får spørsmål om, er design og case. Disse er velkjente i medisinsk sammenheng. Begge er normerte som hankjønnsord (designen og casen), men et nettsøk viser at de oftest blir brukt som intetkjønnsord. Det er vel ikke utenkelig at språkbruken i disse tilfellene har endret seg og festet seg etter at ordene ble normert, står det i Språknytt-artikkelen.

\section{Av interesse for leger}

Dette sveipet gjennom Språknytt, som nå er i sin 39. årgang, viser at her er atskillig

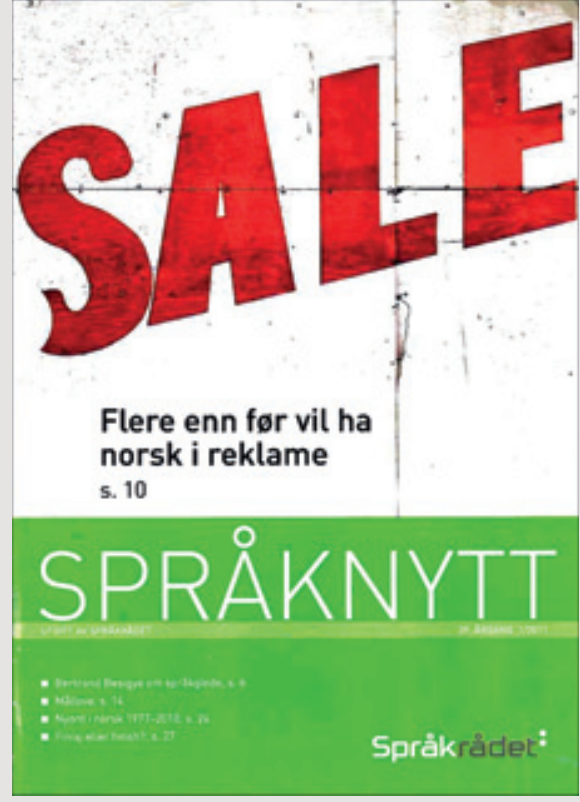

Språknytt har mye av interesse for språkinteresserte leger. Faksimile av Språknytt nr. 1/2011

av interesse også for språkinteresserte leger. Gratisabonnement fås ved henvendelse til Språkrådet. Fulltekstversjon finnes også på deres nettsider (2).

\section{Erlend Hem}

erlend.hem@medisin.uio.no

Tidsskriftet

Erlend Hem (f. 1970) er dr.med. og assisterende redaktør i Tidsskriftet.

Litteratur

1. Solberg S. Manglende troverdighet i Oslo universitetssykehus. Tidsskr Nor Legeforen 2010: 130 : 2109-10

2. Språknytt. www.sprakradet.no/nb-no/Toppmeny/ Publikasjoner/Spraaknytt (10.6.2011).

Mottatt 11.6. 2011 og godkjent 15.6. 2011 Medisinsk redaktør Raida Ødegaard. 